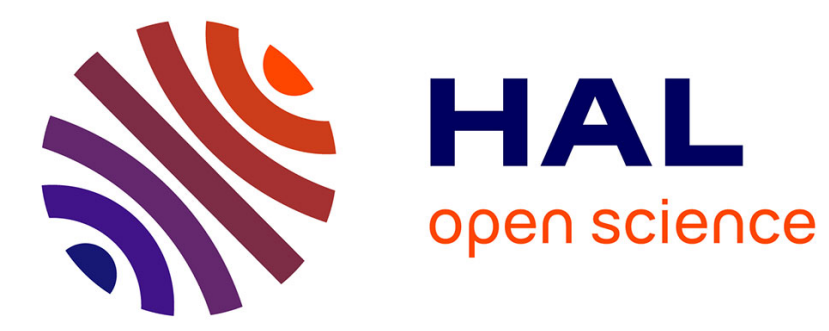

\title{
Observation scales to suspect dyspnea in non-communicative intensive care unit patients
}

Alexandre Demoule, Romain Persichini, Maxens Decavele, Capucine Morélot-Panzini, Frédérick Gay, Thomas Similowski

\section{- To cite this version:}

Alexandre Demoule, Romain Persichini, Maxens Decavele, Capucine Morélot-Panzini, Frédérick Gay, et al.. Observation scales to suspect dyspnea in non-communicative intensive care unit patients. Intensive Care Medicine, 2018, 44 (1), pp.118 - 120. 10.1007/s00134-017-4934-6 . hal-01688177

\section{HAL Id: hal-01688177 https: / hal.sorbonne-universite.fr/hal-01688177}

Submitted on 19 Jan 2018

HAL is a multi-disciplinary open access archive for the deposit and dissemination of scientific research documents, whether they are published or not. The documents may come from teaching and research institutions in France or abroad, or from public or private research centers.
L'archive ouverte pluridisciplinaire HAL, est destinée au dépôt et à la diffusion de documents scientifiques de niveau recherche, publiés ou non, émanant des établissements d'enseignement et de recherche français ou étrangers, des laboratoires publics ou privés. 


\title{
Observation scales to suspect dyspnea
}

\section{in non-communicative intensive care unit patients}

\author{
Alexandre DEMOULE, M.D., PhD. ${ }^{1,2}$, Romain PERSICHINI, M.D. ${ }^{1}$, Maxens DECAVELE, \\ M.D. ${ }^{1,2}$, Capucine MORELOT-PANZINI, M.D., Ph.D. ${ }^{1,2}$, Frédérick GAY, M.D., Ph.D. ${ }^{3 *}$, \\ Thomas SIMILOWSKI, M.D., Ph.D. ${ }^{1,2 *}$
}

${ }^{*}$ The first last authors contributed equally to this work

(1) AP-HP, Groupe Hospitalier Pitié-Salpêtrière-Charles Foix, Service de Pneumologie et Réanimation Médicale (Département "R3S"), F-75013, Paris, France

(2) Sorbonne Universités, UPMC Univ Paris 06, INSERM, UMRS1158 Neurophysiologie respiratoire expérimentale et clinique, Paris, France

(3) AP-HP, Groupe Hospitalier Pitié-Salpêtrière-Charles Foix, Pôle Biologie Médicale et Pathologie, Service de Parasitologie et Mycologie, F-75013, Paris, France

\section{Correspondence:}

Pr Alexandre DEMOULE

Department of Respiratory and Critical Care Medicine

Pitié-Salpêtrière Hospital

47-83 Bd de l’Hôpital

75651 Paris Cedex 13

France

Telephone: 33142167888

E-mail: alexandre.demoule@psl.aphp.fr 
Funding. This study was supported by “Association pour le Développement et l'Organisation de la Recherche en Pneumologie et sur le Sommeil," Paris, France, and by the program “Investissement d'Avenir ANR-10-AIHU 06” of the French Government.

Competing interests. AD has signed research contracts with Covidien/Medtronic, Maquet, Philips and Ait Liquide Santé; he has also received personal fees from Covidien/Medtronic, Maquet, Resmed, Hamilton, Fisher \& Paykel and MSD. TS has received grant research from Coviden, Philips, Pierre Fabre Médicaments, Air Liquide Medical Systems; he has also received personal fees from Takeda, Teva Pharma, Lungpacer Inc, Almirall France, Pierre Fabre Médicaments, Novartis, Mundipharma, Invacare, Astra Zeneca, Boehringer Ingelheim and GlaxoSmithKline. RP, FG, MD and CMP declare that they have no competing interests.

Word count. 582. 
Dyspnea, like pain, is a major cause of physical suffering and emotional distress. In the intensive care unit, mechanically ventilated patients are at high risk of dyspnea [1] and increasing attention is given to this symptom [1,2]. Because its evaluation relies on selfreport and self-assessment [3], dyspnea carries the risk of being underestimated or even unrecognized and therefore unattended in many intensive care unit patients. This is particularly so in patients unable to communicate with their caregivers (sedation, delirium ...). We recently developed and validated a specific intensive care unit version of the respiratory distress observation scale (IC-RDOS, http://www.ic-rdos.com) [4]. IC-RDOS, based on respiratory and behavioural signs, correlates strongly with ratings of dyspnea on a visual analogic scale in "communicative" patients, but this is by definition not the most pertinent target population. The present secondary analysis describes IC-RDOS in "noncommunicative" intensive care unit patients, as the first step of its clinical and prognostic evaluation in this setting.

The 120 communicative patients of the yet reported cohort were compared to 73 noncommunicative patients (sedation, $\mathrm{n}=49$; delirium, $\mathrm{n}=9$; not understanding the questions/instructions, $\mathrm{n}=6$; or another cause, $\mathrm{n}=9$ ) admitted during the same 4.5 months period. Clinical data were gathered during the first 24 hours of the intensive care unit stay, between 8 and 10 a.m. Based on the 21 observable variables with possible clinical relevance (namely, to detect dyspnea) among the 120 communicative patients, the selection started with a principal component analysis which identified 11 explanatory variables that mostly contributing to the principal axes. These variables were entered into an iterative partial least square regression process that ultimately identified 5 variables, of which the combination and weighting allowed optimal correlation with dyspnea on a visual analogic scale including: heart rate, use of neck muscles during inspiration, abdominal paradox during inspiration, facial expression of fear and supplemental oxygen which constitute the IC-RDOS. 
In the present principal component analysis, quantitative variables were centered and reduced, binomial variables were treated as " 0 " or " 1 " in a quantitative manner, and the "communicative/non-communicative" variable was treated as an illustrative variable not participating in the building of the factorial analysis.

Expectedly, the non-communicative patients were, compared to the communicative ones, more often mechanically ventilated, more often on supplemental oxygen, more acidotic and had higher severity scores (Table SDC 1). Otherwise, their general characteristics were roughly similar to those of the communicative patients. IC-RDOS values were not different in both groups (2.3 [1.1-3.1] in the communicative patients, versus 2.4 [2.2-2.7] in the noncommunicative ones, $\mathrm{p}=0.115$ ) although this result should be interpreted with caution since this ancillary study was underpowered to address such comparison. These two subpopulations as well as their corresponding centers of gravity were further plotted and compared on the main factorial plan (F1 X F2) expressing $57.23 \%$ of the total inertia. Beyond the similarity in IC-RDOS values, the projections of the two sub-populations (communicative and non-communicative patients) first had very nearly centers of gravity, second were geometrically congruent (Figure 1), attesting the homogeneity of the communicative and non-communicative populations in terms of physical and behavioral manifestations based on the five IC-RDOS variables.

These results suggest that IC-RDOS could be of value to identify non-communicative intensive care unit patients experiencing dyspnea. This hypothesis will have to be verified, for example by studies testing the responsiveness of IC-RDOS to interventions known to alleviate dyspnea in the intensive care unit context [1], like this has been done for RDOS in palliative care [5]. 


\section{References}

1. Schmidt M, Banzett RB, Raux M, Morelot-Panzini C, Dangers L, Similowski T, Demoule A (2014) Unrecognized suffering in the ICU: addressing dyspnea in mechanically ventilated patients. Intensive Care Med 40: 1-10

2. Chanques G, Nelson J, Puntillo K (2015) Five patient symptoms that you should evaluate every day. Intensive Care Med 41: 1347-1350

3. Binks AP, Desjardin S, Riker R (2017) ICU Clinicians Underestimate Breathing Discomfort in Ventilated Subjects. Respir Care 62: 150-155

4. Persichini R, Gay F, Schmidt M, Mayaux J, Demoule A, Morelot-Panzini C, Similowski T (2015) Diagnostic Accuracy of Respiratory Distress Observation Scales as Surrogates of Dyspnea Self-report in Intensive Care Unit Patients. Anesthesiology 123: $830-837$

5. Campbell ML, Templin T, Walch J (2010) A Respiratory Distress Observation Scale for patients unable to self-report dyspnea. J Palliat Med 13: 285-290 
Figure 1. Panel A shows the calculation of the Intensive Care Respiratory Distress Observation Scale (IC-RDOS). An IC-RDOS $\geq 2.4$ predicted a visual analogic scale for dyspnea (D-VAS) of 4 or greater with equal sensitivity and specificity (72\%) in communicative patients. Panel B shows the comparison of the communicative and noncommunicative populations. Patients are plotted on the main factorial plan (F1XF2=57.23\% of the total inertia) from a principal component analysis build with the five variables of the IC-RDOS together with their respective ellipses and barycenters. 


\section{Panel A}

Variables

$0-$

1 - Heart Rate (beats/min)

2-Use of neck muscles during inspiration

if present

if absent

3 - Abdominal paradox

during inspiration

if present

if absent

4 - Facial expression of fear

if present

if absent

5 - Supplemental oxygen

if present

if absent

\section{Panel B}

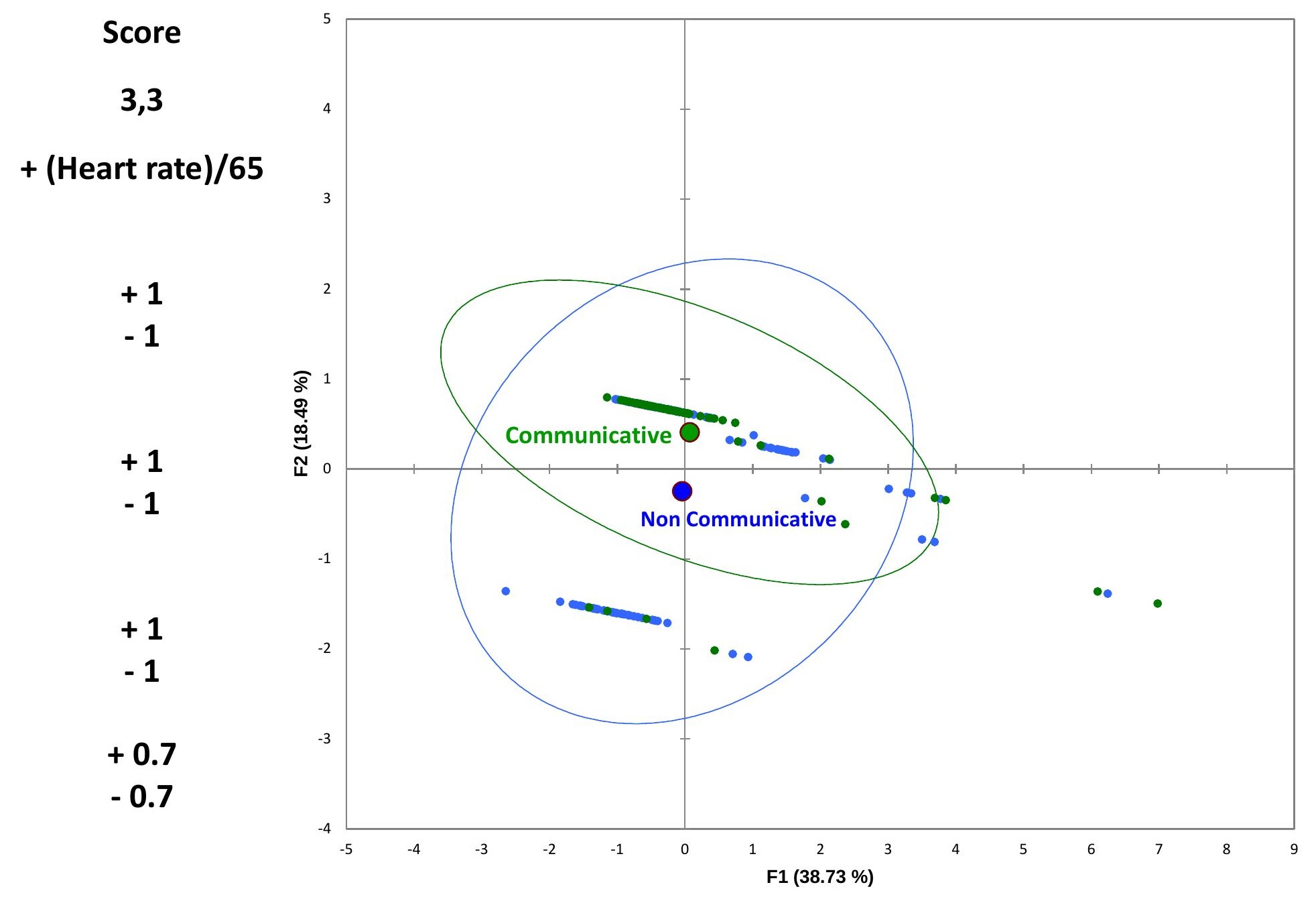


Table SDC 1. Comparison of the communicative $(n=120)$ and non-communicative $(n=93)$ patients in the derivation cohort

\begin{tabular}{|c|c|c|c|}
\hline & $\begin{array}{l}\text { communicative } \\
(n=120)\end{array}$ & $\begin{array}{c}\text { non-communicative } \\
(\mathbf{n}=73)\end{array}$ & $p$ \\
\hline age (y) & $61[46-71]$ & $60[45-73]$ & 0.575 \\
\hline male gender & $60 \%$ & $60 \%$ & 1.000 \\
\hline height $(\mathrm{cm})$ & $1.68[1.60-1.73]$ & $1.70[1.65-1.77]$ & 0.431 \\
\hline weight (kg) & $71[60-83]$ & $73[60-90]$ & 0.365 \\
\hline BMI $\left(\mathrm{kg} / \mathrm{m}^{2}\right)$ & $25[21-28]$ & $25[22$ - 27] & 0.768 \\
\hline respiratory admission & $63 \%(76 / 120)$ & $44 \%(32 / 73)$ & $0.011^{*}$ \\
\hline oxygenotherapy & $66 \%(79 / 120)$ & $93 \%(68 / 73)$ & $<0.0001 *$ \\
\hline mechanical ventilation & $12 \%(14 / 120)$ & $75 \%(55 / 73)$ & $<0.0001^{*}$ \\
\hline HR (beat/min) & $95[80-105]$ & $91[77$ - 108] & 0.628 \\
\hline RR (cycle/min) & $22[18-26]$ & $20[18-25]$ & 0.238 \\
\hline systolic APB (mmHg) & 123 [110 - 135] & 117 [102 - 135] & 0.165 \\
\hline diastolic ABP (mmHg) & $65[56-75]$ & $58[53-70]$ & 0.042 \\
\hline $\mathrm{SpO}_{2}(\%)$ & 97 [95 - 99] & 98 [96 - 100] & 0.036 \\
\hline $\mathrm{PaO}_{2}(\mathrm{mmHg})$ & 81 [70 - 93] & 98 [76 - 124] & $0.001 *$ \\
\hline $\mathrm{PaCO}_{2}(\mathrm{mmHg})$ & 37.7 [32.5 - 45.9] & $37.5[32.3-48.7]$ & 0.772 \\
\hline $\mathrm{HCO}_{3}{ }^{-}(\mathrm{mmol} / \mathrm{l})$ & $25.2[20.9-29.1]$ & $22.5[18.7-26.6]$ & 0.017 \\
\hline $\mathrm{pH}$ & $7.41[7.36-7.47]$ & $7.35[7.27-7.42]$ & $<0.0001^{*}$ \\
\hline $\mathrm{Hb}(\mathrm{g} / \mathrm{dl})$ & $11.6[9.7-13.5]$ & $11.2[9.1-13.1]$ & 0.207 \\
\hline lactate (mmol/l) & $1.4[1.0-2.0]$ & $1.9[1.2-2.6]$ & 0.009 \\
\hline temperature $\left({ }^{\circ} \mathrm{C}\right)$ & $37.0[36.4-37.5]$ & $37.0[36.0-37.7]$ & 0.851 \\
\hline SAPSII & $33[21-43]$ & $61[45-75]$ & $<0.0001 *$ \\
\hline RDOS & $2[1-3]$ & $2[1-3]$ & 0.816 \\
\hline IC-RDOS & $2.3[1.1-3.1]$ & $2.4[2.2-2.7]$ & 0.115 \\
\hline
\end{tabular}

Data are expressed as median [interquartile range] for quantitative data and frequency (\%) for qualitative data.

Univariate comparisons were conducted between the communicative and non-communicative patients using Fisher's exact test for binomial variables and the Mann-Whitney U-test for quantitative variables. 
The "*" symbol denotes p values below 0.05 that remained significant after correction for multiple comparisons according to Benjamini-Hochberg procedure (see methods); corrected $\mathrm{p}$-value for this table $=0.0117$.

BMI: body mass index; ABP: arterial blood pressure; HR: heart rate; RR: respiratory rate; $\mathrm{Hb}$ : hemoglobin; $\mathrm{SpO}_{2}$ : pulse oximetry; SAPSII: simplified acute physiology score II, RDOS: respiratory distress observation scale, IC-RDOS: intensive care - respiratory distress observation scale, IC-RDOS. 